(C) Copyright 2019: Editum. Servicio de Publicaciones de la Universidad de Murcia. Murcia (Spain) ISSN print edition: 0212-9728. ISSN on line edition (http://revistas.um.es/analesps): 1695-2294. On line edition License Creative Commons 4.0: BY-NC-ND

\title{
Bullying and depression: the moderating effect of social support, rejection and victimization profile
}

\author{
Ascensión Palomares-Ruiz ${ }^{1 *}$, Arantxa Oteiza-Nascimento ${ }^{2}, \mathrm{M}^{\mathrm{a}} \mathrm{Paz}_{\text {Toldos}}^{3}$, Isabel Serrano-Marugán ${ }^{4}$, and \\ Javier Martín-Babarro ${ }^{5}$ \\ 1 Facultad de Educación, Universidad de Castilla-La Mancha (Spain) \\ 2 IES Alonso Quijano, Alcalá de Henares, Madrid (Spain) \\ 3 E. Humanidades y Educación, Instituto Tecnológico y E. Superiores, Monterrey (México) \\ 4 Facultad de Psicología, UNED (Spain) \\ 5 Facultad de Psicologia, Universidad Complutense (Spain)
}

\begin{abstract}
Título: Acoso escolar y depresión: el efecto moderador del apoyo social, el rechazo y el perfil de la victimización.

Resumen: Las relaciones dentro del grupo de iguales pueden conformarse como factores influyentes en la prevalencia de los episodios de acoso escolar. Esta investigación tiene como objetivo analizar el efecto del acoso escolar sobre los niveles de depresión de las víctimas y en qué medida se ve afectado por el apoyo social, el estatus en el grupo y por el perfil de la victimización. Se calcularon varios modelos de regresión jerárquica lineal, en una muestra de 1063 alumnos, entre 10 y 14 años ( $47.8 \%$ de chicas; $M=$ 11.59 años, $D T=1.21$ años), de 10 centros educativos de la Comunidad de Madrid. Se observó el grado de influencia de las variables estudiadas: falta de apoyo social, rechazo de los pares, conductas de retraimiento y de impulsividad, y la relación de todas ellas con la victimización y la depresión. Los resultados revelaron la influencia de la falta de apoyo social en los alumnos victimizados sobre la depresión. Sin embargo, el rechazo de los iguales no mostró influencia sobre los niveles de depresión de las víctimas. Además, las víctimas con características de tipo internalizante mostraron una mayor asociación con la depresión que las víctimas con características externalizantes.

Palabras clave: Acoso escolar; Victimización; Depresión; Apoyo social
\end{abstract} Rechazo entre iguales.

\section{Introduction}

Bullying at school is considered a situation in which violence is perpetrated intentionally on the basis of a power asymmetry, by a schoolchild or group of schoolchildren towards another schoolchild. According to Cerezo, Sánchez, Ruiz and Arense (2015), it is a complex phenomenon caused by the influence of both individual factors relating to the aggressor and the victim and the environment in which they interact, with them all forming a framework of action in which these behaviours develop.

Research has shown that bullying at school is a global phenomenon, and though more attention has been paid to studying individual variables (Postigo, González, Montoya \& Ordoñez, 2013), it is important to address it as a multifactorial issue. This is why, in analysing bullying at school, current explanatory models propose an ecological perspective, with special attention being paid to the context in which it occurs: the school itself (Machimbarrena \& Garaigordobil, 2017).

* Correspondence address [Dirección para correspondencia]: Ascensión Palomares-Ruiz. Facultad de Educación de Albacete. Universidad de Castilla-La Mancha. Plaza de la Universidad, 3. CP. 02071. Albacete (Spain). E-mail: ascension.palomares@uclm.es

(Article received: 28-07-2017; revised: 1-5-2018; accepted: 1-05-2018)
Abstract: Peer relationships can be shaped as influential factors in the prevalence of bullying episodes. This research aims to analyze the effect of school bullying on the levels of depression of the victims and to what extent it is affected by social support and status in the group and by the profile of victimization. Several hierarchical linear regression analyses were calculated, in a sample of 1063 students aged 10 to 14 (47.8\% of girls, $M=$ 11.59 years, $S D=1.21$ years), from 10 school of the Region of Madrid. The degree of influence of the studied variables was observed: lack of social support, peer rejection, withdrawal and impulsivity behaviors, and the relationship of all of them with victimization and depression. Findings revealed the influence of the lack of social support on the depression of victimized students. However, peer rejection did not show influence on the levels of depression of the victims. In addition, victimization associated with internalizing characteristics showed a greater association with depression than victimization associated with an externalizing profile.

Keywords: Bullying; Victimization; Depression; Friendship; Peer rejection.
Bullying at school is a group process in which the roles of all the group's participants influence the process and the peer-to-peer dynamic, encouraging or limiting its prevalence (Huitsing \& Veenstra, 2012; Salmivalli, 2010). Among these roles there are three major groups: victims, aggressors or bullies, and bystanders. The victim group has been found to be heterogeneous. Researchers have identified a subgroup of passive victims (Olweus, 1978, 1993), or victim/rejected (Perry, Kusel \& Perry, 1988), and hostile victims (Martínez \& Delgado, 2006), also known by other authors as 'aggressive victims' (e.g. Toblin, Schwartz, Hopmeyer Gorman \& Abo-ezzeddine, 2005; Unnever, 2005; Veenstra, Lindenberg, Oldehinkel, De Winter, Verhulst \& Ormel, 2005) or 'provocative victims' (Boulton \& Underwood, 1992; Olweus, 1993, 2001; Pellegrini, Bartini \& Brooks, 1999; Perry et al., 1988; Schwartz et al., 1998) or bully/victims (Boulton \& Smith, 1994; Haynie et al., 2001). Both active and passive victims lack suitable strategies to find solutions and tackle the problem. However, while aggressive victims respond with violence and minimise the act of violence, passive victims become paralysed with fear, powerless and often feel to take the blame for the violence inflicted on them, becoming resigned to it (Avilés, 2009; Nolasco, 2012).

Victims with a passive profile are described as insecure, suffering from low self-esteem, anxious, unassertive and 
lacking in social and communication skills. They are usually students who are physically weak, introverted and tend to act in a repressed manner, giving the impression that they do nothing to provoke attacks or defend themselves from them (Nolasco, 2012). Provocative or active victims are described as restless, irascible and anxious, and attempt to retaliate when attacked (Olweus, 1978). They tend to react impulsively and display irritation, aggression, a desire to dominate and an anti-social nature, reacting with excessive hostility and participating more frequently in situations involving physical aggression than out-and-out bullies (Olweus, 2001).

As regards the relationship between victimisation, aggression and peer rejection, authors such as Olweus (1993) describe the passive victim as being solitary and a loner at school, who is characterised by being socially isolated, who often does not have any friend among their peers, and whose lack of popularity only intensifies when they are victimised. Aggressive victims tend to be rejected and have few friends (Pellegrini et al., 1999; Salmivalli \& Nieminen, 2002), and also receive worse assessments from teachers (Unnever \& Cornell, 2003).

It has been widely found that the effects of group influence affect the psychological adjustment of the student in question (Juvonen, Graham \& Shuster, 2003). In the case of the victim, suffering such unprovoked aggression causes them behavioural and emotional maladjustment, as has been seen in a number of studies (Huitsing \& Veenstra, 2012; Olweus, 1978; Perry et al., 1988). These behavioural maladjustments have been categorised into two major groups: (a) internalising (withdrawal and submission), and (b) externalising (active defence) (Achenbach \& Edelbrock, 1978). The most common form of response of these individuals is internalising behaviour, caused by the power the aggressor projects towards them. The other form of response manifests itself through externalising behaviour that takes the form of nervousness, impulsiveness, hyperactivity, anti-social behaviour and aggression.

Research has shown that there are correlations between victimisation and the constructs that characterise aggressive victims (e.g. externalising behaviour) and passive victims (e.g. internalising behaviour) (Boivin, Hymel \& Bukowski, 1995; Hodges, Malone \& Perry, 1997; Schwartz, McFadyenKetchum, Dodge, Pettit \& Bates, 1998). Some authors have found that internalising and withdrawn behaviours are linked to victimisation, a trait of passive victims, and externalising behaviours to the reactive aggression of active victims (Kochenderfer \& Ladd, 1996; López, Bilbao \& Rodríguez, 2012). Studies such as that conducted by Martínez and Delgado (2006) find that individuals who attack others (aggressors and aggressive victims) show more in the way of externalising behaviour and impulsiveness than prosocial behaviour. In contrast, individuals who display traits associated with passive victims are characterised as being withdrawn and communication difficulties.

In addition to individual risk factors, such as certain styles of confrontation that are largely useless in dealing with peer aggression, there are other factors relating to the context, regarded by some authors as social risk factors: lack of support and peer rejection (Hodges, Malone \& Perry, 1997). Studies show that victimised students who receive some type of support suffer fewer maladjusted responses than students who do not (Espelage \& Holt, 2013). By the same token, it is recognised that peer rejection is usually an indicator linked to victimisation (Hodges et al., 1997; Perry et al., 1988). However, there have yet to be a sufficient number studies showing the degree of protection afforded by support, or the risk of rejection, or to what extent they impact on the psychological adjustment of victims.

\section{Victimisation}

In terms of the degree to which a victimised individual is able to overcome the problem, there are specific factors that can impact to a greater extent on the individual effects of this victimisation. Intensity, duration, persistence over time and type of attacks are variables that reveal a direct link with the level of damage (Avilés, 2009; Batsche \& Knoff, 1994; Olweus, 1998; Solberg \& Olweus, 2003). In addition to these variables on an individual level, it has been found that the consequences of victimisation are worse in groups where victimisation is centralised and where, therefore, it is suffered only by a few, all of which feeds the belief that the reasons for bullying at school lie with the victims themselves, which makes them social misfits (Huitsing \& Veenstra, 2012) and leads to them being unable to respond to or defend themselves from attacks (Garandeau \& Cillessen, 2006). In the face of this avoidance behaviour, the group deduces that the victims will not respond to attacks because they feel responsible for what is happening (Avilés \& Monjas, 2005; Juvonen \& Graham, 2001) or they deem that it is not a big issue and thus do nothing to prevent attacks from occurring (Salmivalli, 2010).

The main difference between passive and active victims (Olweus, 1978; Perry et al., 1988; Schwartz, Dodge \& Coie, 1993) lies in how they react when being attacked and in the resulting effects. The passive victims tend not to defend themselves, show internalising behaviour in an effort to avoid being attacked again, and usually suffer higher levels of anxiety and depression (Batsche \& Knoff, 1994; Branson \& Cornell, 2009). The active victim uses reactive aggression as a response to the aggressor's attacks, their behaviour is externalising, more aggressive and impulsive (Martínez \& Delgado, 2006; Perry et al., 1988), and they show high levels of depression and levels of anxiety that are above the mean (Branson \& Cornell, 2009). Studies indicate that both internalisation and externalisation behaviours point to increases in victimisation levels (Hodges \& Perry, 1999).

Researchers agree that victims who have no support from their peers in the class group are the most vulnerable (Veenstra, Lindenberg, Munniksma \& Dijkstra, 2010). Aggressors usually exert their power over the most vulnerable individuals to prevent defence and counterattack from oc- 
curring (Garandeau \& Cillessen, 2006). An individual who has no social support or lacks a stable network in their peer group will thus be at greater risk of being victimised (Peets, Hodges \& Salmivalli, 2011). The role of the victim, together with a lack of support from their peers, causes increased suffering, which thus impacts on their psychological adjustment.

\section{Social support}

Social support is defined as the network formed by an individual's meaningful interpersonal relationships and which help them maintain a suitable psychological and social adjustment and provide them with a secure framework for responding to problems (Manga, Abella, Barrio \& Álvarez, 2007). Research on the effects of bullying on victimised students, in relation to support from teachers and/or peers, reveals a significant difference in the case of peers. Although the lowest levels of maladjustment are linked to both types of support, it is peers who offer greater adjustment, which clearly indicates their mitigating impact (Flaspohler, Elfstrom, Vanderzee, Sink \& Birchmeier, 2009).

Receiving social support within the group is, in itself, a protection factor. It has been shown that students with social support are less victimised than those without friends in the group (Hodges et al., 1997; Hodges \& Perry, 1999; Salmivalli, 2010). Support from friends in response to stressful situations in interpersonal relations can influence internalisation and externalisation responses linked to victimisation. It can, on occasion, prevent attacks (Salmivalli, 2010) and also lessen the negative effects of bullying on victims (Pellegrini et al., 1999). It can also reduce levels of emotional maladjustment by reducing negative feelings of guilt (Flaspohler et al., 2009; Holt \& Espelage, 2007) and encourage a positive desire to confront the problem. What is more, in cases in which bullying at school persists, the victim's experience and its effects are less serious in nature when they have some kind of social support, as the sense of vulnerability they feel is reduced (Hodges \& Perry, 1999).

Research shows that social support of victimised students is usually lower than that received by the rest of their peers in the classroom (Schwartz et al., 1993), with victims receiving social support being noted as having lower levels of anxiety and depression and greater self-esteem than students with no social support. Similarly, the lack of social support received by victimised students is more closely linked to suicidal thoughts than in individuals who have social support (Espelage \& Holt, 2013; Rigby, 2002; Sainio, Veenstra, Huitsing \& Salmivalli, 2010).

\section{Peer rejection}

Peer rejection has been defined as a group construct (along with peer acceptance), and has a major influence on general group feelings (Buhs \& Ladd, 2001). Consequently, students belonging to the group of aggressors and victims attract the highest levels of rejection from their peers (Mar- tínez \& Delgado, 2006; Olweus, 1978). However, although the expectation would be for aggressors to suffer higher levels of rejection, empirical evidence suggests that they are popular among their peers (Pellegrini et al., 1999). In other words, aggressors can be popular and lead other groups of aggressors, as certain forms of aggression (proactive or instrumental) appear to be linked to membership of these groups (Cairns, Cairns, Neckerman, Gest \& Gariepy, 1988). As this is a type of aggression that is used in order to achieve an aim, it is employed by the aggressor to display a level of competence to other groups, thus reinforcing their command and leadership in the eyes of other groups. It is thus victimised students who receive the greatest number of rejections (Perry et al., 1988; Salmivalli, 2010). And though they are normally bullied by a single individual, they usually suffer the rejection of a large number of peers within their peer group (Graham \& Juvonen, 1998).

On a personal level, and depending on the similarity model, rejection and acceptance are motivated by the tendency of individuals to accept others who are like them and reject anyone they consider to be different (Olweus, 1978; Wright, Giammarino \& Parad, 1986).

If victims are assessed in accordance with their response to attacks, research has shown that active victims are the most vulnerable of groups (Garandeau \& Cillessen, 2006; Juvonen et al., 2003; Perry et al., 1988). Though they respond to attacks by aggressors with reactive aggressive behaviour, due to their lack of social ability and the fact they lack social support they interact with inappropriate behaviour, acting nervously and aggressively, usually to the annoyance of the peer group and eliciting a high level of rejection from them, giving them reason to engage in fresh assaults (Martínez \& Delgado, 2006; Olweus, 1978; Perry et al., 1988). It has also been noted that depressed behaviour or complaining causes a lack of support from peers and is very closely linked to the possibility of being victimised (Hodges et al., 1997; Kochenderfer \& Ladd, 1996) and thus being rejected by peers (Garandeau \& Cillessen, 2006; Perry et al., 1988; Schwartz et al., 1993).

\section{Psychological maladjustments}

Some studies have revealed significant links between victimisation and emotional maladjustments (Branson \& Cornell, 2009; Graham \& Juvonen, 1998; Juvonen et al., 2003), with victimised individuals revealing high levels of depression (Batsche \& Knoff, 1994; Hodges \& Perry, 1999), anxiety (Branson \& Cornell, 2009; Martínez \& Delgado, 2006; Veenstra et al., 2010), low self-esteem and a lack of quality relationships with peers (Huitsing \& Veenstra, 2012). Victimised students with a more passive profile learn that the characteristics of the aggressor (physical, emotional and/or social) are superior. As a result of this, they feel impelled to submit themselves to the aggressor. This causes them to feel sad and insecure, feelings that are reflected in high levels of depression and anxiety (Branson \& Cornell, 2009; Olweus, 
1994) and low self-esteem (Huitsing \& Veenstra, 2012). Students with a more active profile attempt to respond to attacks, but the imbalance of power (physical, psychological, emotional) that they suffer reduces their chances of success, which is reflected in their low self-esteem, above average levels of depression (Swearer, Song, Cary, Eagle \& Mickelson, 2001) and deep anxiety (Branson \& Cornell, 2009; Martínez \& Delgado, 2006).

The consequences of assaults may be slight, lasting, result in long-term effects that last into adult life or, in the most serious of cases, result in the individual committing suicide (Espelage \& Holt, 2013). Although psychological maladjustments can be internalising and externalising, studies show that social victimisation is a major contributor to the appearance of internalising disorders, and physical victimisation to externalising disorders. It is aggressive victims who have the greatest adjustment difficulties, however, both in terms of internalisation and externalisation behaviours (Juvonen et al., 2003; Veenstra et al., 2010).

To ensure that they achieve their objectives (power, control and status), aggressors thus choose victims who have little social support and, if possible, are rejected by the group (Garandeau \& Cillessen, 2006; Perry et al., 1988; Salmivalli, 2010). Students presenting these two risk factors become more vulnerable and can be expected to suffer an increase in adjustment problems in the face of aggression from their peers (Hodges \& Perry, 1999).

In a study in which the behavioural problems of students were compared in accordance with their victimisation, it was found that having few friends, having friends incapable of offering protection or being rejected in the peer group were three factors that have a significant correlation with psychological internalisation and externalisation maladjustments (Hodges et al., 1997). In pursuing this line of research, this study aims to analyse the relationship between victimisation in school bullying and depression, and how this relationship is influenced by social status and the profile of victimisation.

\section{Objectives and hypotheses}

This study is founded on the premise that victimisation is an indicator of depression, especially in active victims, with risks increasing when the individual lacks the social support that would protect them or alleviate their discomfort and sees themselves as being rejected by the group. We have therefore set the following objectives: a) to study the degree of influence that these social risk factors (lack of social support and peer rejection) in victimisation have on rates of depression and the degree of importance that can be attached to them, with a view to ascertaining which effect is most pernicious: lack of support or peer rejection; and, as objective b): to identify the influence of these variables in relation to the internalising or externalising traits of the victims.

It is expected that a higher level of depression will be found among victims than non-victims (Hypothesis 1). The social situation of the victim is measured by means of two variables: lack of social support and peer rejection, both in reference to the class group. It is expected that a higher level of depression will be found in victims of bullying at school who receive no social support in the class group than in victims with support in the group (Hypothesis 2a). It is also expected that a higher level of depression will be found in victimised students who have been rejected by the group ( $\mathrm{Hy}-$ pothesis $2 \mathrm{~b}$ ). It is also posited that the maladjusted response of victimised individuals is not the same in all cases. The personality traits of victimised students are expected to produce different effects. It is expected that a higher level of depression will be found in those individuals with higher levels of internalisation than in students with higher levels of externalisation (Hypothesis 3).

\section{Method}

\section{Participants and procedure}

The participants in this study constitute a subsample from a broader study funded by the Official College of Psychologists of Madrid and the Atresmedia Foundation for the analysis of the psychological maladjustment of the victims of bullying at school. It was obtained by means of non-random sampling and using a cross-sectional design, and comprises 1,063 students $(47.8 \%$ of them girls; $M=11.59$ years, $S D=$ 1.21 years) belonging to the last two years of primary education and the first two of secondary (primary 5th yr, $n=291$; primary 6th yr, $n=217$; secondary 1 st yr, $n=197$ and secondary 2 nd $\mathrm{yr}, n=365$ ) from ten schools (six state and four private) in the Autonomous Region of Madrid. The families of the project participants were informed of the objectives and content of the study and were invited to give their permission to the students being assessed. The participants responded individually through an online application in the computer room at each school over the course of an hour of lesson time. The questions were grouped together on screen and on different pages, in such a way that participants had to answer one page of questions before accessing the next. Participants were informed that their answers were anonymous and that the confidential nature of the information would thus be respected.

\section{Variables and instruments}

Victimisation was measured through hetero-reporting. Before the questions were put to the students, they were shown an adapted definition of bullying at school by Olweus (1998). Three items for measuring different types of bullying at school were then presented - one oriented towards measuring physical victimisation ("Which classmate is hit or physically mistreated by others, with advantage being taken of their weakness in the group?'); another towards verbal victimisation (Which classmate is insulted or humiliated by other classmates?'); and a third towards social victimisation (Which classmate has become isolated from the group or ig- 
nored?'). The number of nominations received by each individual in each item is divided by the number of classmates answering the questionnaire. Finally, and following a calculation method based on that proposed by Goossens, Olthof and Dekker (2006), the variable considering individuals nominated by at least $15 \%$ of peers from their class group as victims was dichotomised.

Ten items were used to measure depression as a factor related to the presence of a low mood and sadness (e.g.: 'I don't think I have a good life', 'I sometimes wish I were someone else') with five response levels (never, rarely, sometimes, often, very often). The scale used was validated by Martín, Ruiz and Martínez (2014) (Alpha $=.78)$. Points were added up to calculate the final score.

Social withdrawal, regarded as social isolation, lack of participation in the group and shyness, was measured by ten items (e.g.: 'I usually keep quiet to avoid putting my foot in it', 'I don't enjoy it when I have to speak in front of the class') with five response levels (never, rarely, sometimes, often, very often). Points awarded for the items were added up to calculate the final score. The scale used was validated previously by Martín et al. (2014) (Alpha = .79)

Impulsiveness-byperactivity was measured with a self-report scale focused on two aspects of attention deficit hyperactivity disorder. The scale is composed of 11 items (example of an item on hyperactivity: 'I find it hard to sit still'; example of an item on impulsiveness: 'I'm impatient') with five response levels (never, rarely, sometimes, often, very often). The points awarded for the items were added together in calculating the final score. The scale was validated previously through a factorial analysis that revealed a common structure for both types of items (impulsiveness and hyperactivity) (Martín et al., 2014) (Alpha $=.86)$. Similar results have been encountered in previous studies with different samples (Parellada, San Sebastián \& Martínez, 2009).

The social support variable was obtained through heteroreporting. Students answered the following question: "Who are your friends?" in the class group, with a maximum of nine nominations. In calculating this variable, the friendship nominations received were taken into account. The variable was dichotomised, with a value of 0 being assigned to individuals who received two or more friendship nominations in the class group, while the value of 1 was assigned to those individuals who received one friendship nomination or none at all.

The rejection variable was calculated using the sociometric method of ratings obtained through hetero-reporting, using the question: "Please rate how well you get on with each and every one of your peers". Through the use of a seven-point Likert scale (very badly, badly, not very well, neither like nor dislike, a little, quite well, very well), information was obtained on all possible relations in the class group. The social preference of each student was then calculated using the procedure of Asher and Dodge (1986). The positive response options were added together and calculated as posi- tive nominations. The rejection response options were then added together in order to measure the negative nominations. A social preference rating was calculated for each student, with negative nominations being subtracted from positive nominations and the final scores being converted into typical scores. Finally, a cut-off point was set, with consideration given to scores below $-1 \mathrm{SD}$, which represented the students suffering most rejection in each group. This provided a mean of 221 individuals rejected by each group of students, as opposed to a mean of 302 rejected students obtained by applying the sociometric categories method of Coie, Dodge and Coppotelli (1982).

\section{Data analysis}

SPSS 22.0 (SPSS Inc., 2013) software was used to analyse data. Descriptive statistics and correlations between variables were calculated first of all. Two multiple linear regression models were then calculated. In the first model, the following variables were entered in the first block: victimisation and lack of social support, and the variable comprising both variables. The following variables were entered in the second block: withdrawal, the variable comprising withdrawal and victimisation, and the variable comprising withdrawal, victimisation and lack of social support. The following variables were entered in the third block: impulsiveness-hyperactivity, the variable comprising impulsiveness-hyperactivity and victimisation, and the variable comprising impulsivenesshyperactivity, victimisation and lack of social support. In the second model, victimisation and rejection were entered in the first block, and the variable comprising both variables. The following variables were entered in the second block: withdrawal, the variable comprising withdrawal and victimisation, and the variable comprising withdrawal, victimisation and rejection. The following variables were entered in the third block: impulsiveness-hyperactivity, the variable comprising impulsiveness-hyperactivity and victimisation, and the variable comprising impulsiveness-hyperactivity, victimisation and rejection.

\section{Results}

\section{Descriptive analyses and correlations}

Table 1 shows the descriptive results and correlations between the variables used. Depression was shown as being positively linked with the other variables, though in a more significant way with withdrawal $(r=.469)$ and impulsiveness $(r=.481)$. Withdrawal was also shown as being positively linked with victimisation $(r=.185)$. Victimisation was positively linked with the lack of social support variable $(r=$ $.303)$ and rejection $(r=.411)$. Finally, rejection and the lack of social support variable revealed a positive relationship ( $r=$ .208). 
Table 1. Descriptive statistics and correlations.

\begin{tabular}{lccccc}
\hline & $M E A N$ & $S D$ & 1 & 2 & 3 \\
\hline 1. Depression & 19.21 & 7.05 & & & \\
2. Withdrawal & 23.09 & 6.58 & $.469^{* *}$ & $.158^{* *}$ & $.185^{* *}$ \\
3. Impulsiveness & 21.34 & 5.79 & $.481^{* *}$ & .014 & $.112^{* *}$ \\
4. Victimisation & .02 & .04 & $.135^{* *}$ & .001 & $.303^{* *}$ \\
5. Lack of social support & - & - & $.097^{* *}$ & $.110^{* *}$ & .041 \\
6. Rejection & - & - & $.105^{* *}$ & $.201^{* *}$ \\
\hline
\end{tabular}

\section{Hierarchical multiple linear regression models}

Two regression models were calculated using the steps method. The first of the analyses was based on lack of social support (Table 2), and the second on peer rejection (Table 3).

The results showed that victimisation is positively linked with depression $(b=1.75, t=3.77, p<.001)$. This suggests that victimised students expressed a higher level of depression than non-victimised students. Withdrawal was shown to have a positive link with depression $(b=.43, t=18.13, p<$ $.001)$. The most withdrawn students revealed higher levels of depression than those with lower levels of withdrawal. Lack of social support revealed an interaction effect on the link between victimisation and depression $(b=1.53, t=2.41, p<$ $.05)$. Victimisation was shown to be linked with depression.

Table 2. Regression analysis of the effects of victimisation, social support, withdrawal and impulsiveness on depression.

\begin{tabular}{|c|c|c|c|c|c|c|}
\hline & $B$ & ET & $B$ & $E T$ & $B$ & ET \\
\hline \multicolumn{7}{|l|}{ Block 1} \\
\hline Constant & 18.91 & $.18^{* * *}$ & 9.10 & $.56^{* * *}$ & -.86 & .68 \\
\hline Victimisation & 1.75 & $.46^{* *}$ & -.47 & 1.53 & 3.04 & 1.71 \\
\hline Social support & .72 & .72 & .25 & .64 & .29 & .56 \\
\hline Victimisation $\mathrm{x}$ social support & 1.53 & $.63^{*}$ & 3.46 & 2.52 & 6.05 & $2.87^{*}$ \\
\hline \multicolumn{7}{|l|}{ Block 2} \\
\hline Withdrawal & & & .43 & $.02^{* * *}$ & .38 & $.02^{* * *}$ \\
\hline Withdrawal $\mathrm{x}$ victimisation & & & .09 & $.04^{*}$ & .08 & .05 \\
\hline $\begin{array}{l}\text { Withdrawal } \mathrm{x} \text { victimisation } \\
\mathrm{x} \text { social support }\end{array}$ & & & .49 & $.18^{* *}$ & .48 & $.19^{* *}$ \\
\hline \multicolumn{7}{|l|}{ Block 3} \\
\hline Impulsiveness & & & & & .52 & $.02^{* * *}$ \\
\hline Impulsiveness $\mathrm{x}$ victimisation & & & & & -.11 & .06 \\
\hline $\begin{array}{l}\text { Impulsiveness } \mathrm{x} \text { victimisation } \\
\mathrm{x} \text { social support }\end{array}$ & & & & & .12 & .11 \\
\hline $\mathrm{R}^{2}$ & $2 \%$ & & $22 \%$ & & $39.5 \%$ & \\
\hline
\end{tabular}

However, this relationship was stronger in cases where the victim lacked social support, in comparison with victims who had support in the class group. Although the relationship between victimisation and depression is positive, it is influenced by the social support variable, with the result that victims with low social support presented a significantly higher level of depression than victimised individuals who had support in the classroom (two friends or more). With a view to analysing this interaction effect in greater detail, simple slopes were calculated, and the instructions detailed by Aiken and West (1991) were followed in creating a graph featuring simple slopes and visualising said effect. Such analysis confirmed that victimisation was shown to be linked to depression, although this link was stronger when the victims had little or no social support $(b=3.31, t=2.65, p<.01)$ than when they did have support $(b=.67, t=.64, p=$ n.s. $)$. Although the relationship between victimisation and depression is positive, it is influenced by the social support variable, with the result that victims with no social support presented a significantly higher level of depression than victimised individu- als who had support in the classroom (one or more friends) (Figure 1).

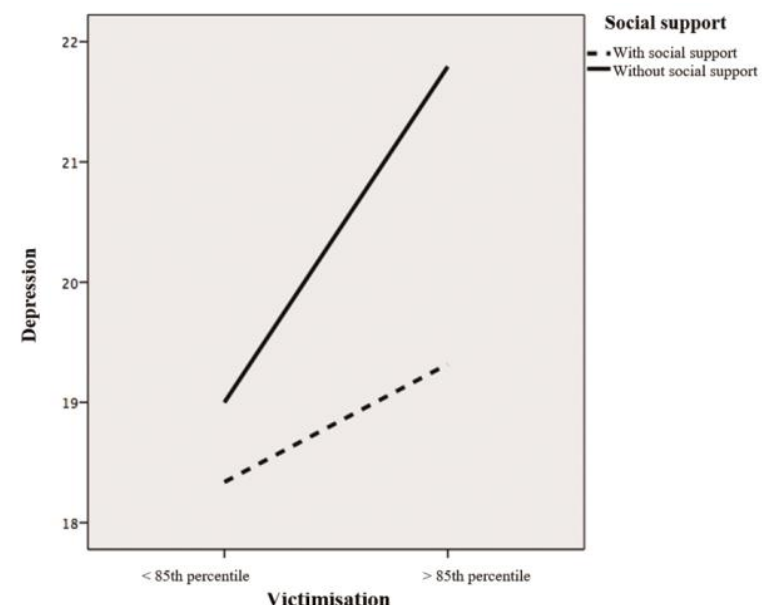

Figure 1. Effect of the double interaction of victimisation and social support on depression. 
Withdrawal and victimisation were shown to have a positive link with depression $(b=.09, t=2.25, p<.01)$. In addition, the social support variable was shown to have an interaction effect with victimisation and withdrawal on depression $(b=.49, t=2.66, p<.01)$. Victims who exhibited high levels of withdrawal and had little social support showed higher levels of depression $(b=8.44, t=6.50, p<.001)$ in comparison to victims with high levels of withdrawal but who did have support in the class group $(b=6.04, t=7.89, p$ $<$.001). The effect on individuals with low levels of withdrawal and a lack of social support could not be checked as said profile was not represented in the sample.

Finally, impulsiveness was also shown to be positively linked to depression $(b=.52, t=20.99, p<.001)$, which indicated the presence of higher levels of depression when students showed higher levels of impulsiveness than when these were lower.

Table 3 shows the analysis of a linear regression model considering rejection as a possible moderating variable. Rejection revealed a slightly positive link with depression $(b=$ $.71, t=3.27, p<.01)$, though it was shown to have no interaction effect on the other variables. In this model, withdraw- al showed a slight moderating effect in the link between victimisation and depression $(b=.83, t=2.33, p<.05)$.

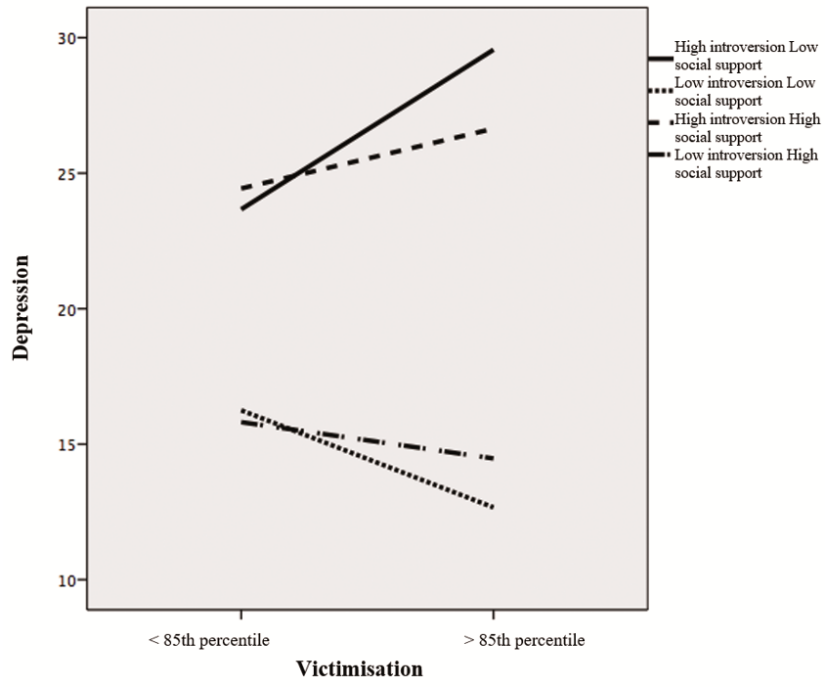

Figure 2. Effect of the triple interaction of withdrawal, social support and victimisation on depression.

Table 3. Regression analysis of the effects of victimisation, rejection, withdrawal and impulsiveness on depression.

\begin{tabular}{|c|c|c|c|c|c|c|}
\hline & $B$ & ET & $B$ & ET & $B$ & ET \\
\hline \multicolumn{7}{|l|}{ Block 1} \\
\hline Constant & 19.09 & $.17^{* * *}$ & 9.29 & $.56^{* * *}$ & -.68 & .69 \\
\hline Victimisation & 2.30 & $.46^{* * *}$ & -1.42 & 1.52 & .47 & 1.76 \\
\hline Rejection & .71 & $.21^{* *}$ & .54 & $.19^{* *}$ & .32 & .17 \\
\hline Victimisation $\mathrm{x}$ rejection & .83 & .35 & -1.38 & 1.08 & .08 & 1.18 \\
\hline \multicolumn{7}{|l|}{ Block 2} \\
\hline Withdrawal & & & .43 & $.02^{* * *}$ & .38 & $.02^{* * *}$ \\
\hline Withdrawal $\mathrm{x}$ victimisation & & & .04 & .06 & .06 & .05 \\
\hline Withdrawal $\mathrm{x}$ victimisation $\mathrm{x}$ rejection & & & .02 & .04 & .02 & .03 \\
\hline \multicolumn{7}{|l|}{ Block 3} \\
\hline Impulsiveness & & & & & .52 & $.03^{* * *}$ \\
\hline Impulsiveness $\mathrm{x}$ victimisation & & & & & .05 & .06 \\
\hline Impulsiveness $\mathrm{x}$ victimisation $\mathrm{x}$ rejection & & & & & .04 & .04 \\
\hline $\mathrm{R}^{2}$ & $3 \%$ & & $21 \%$ & & $39 \%$ & \\
\hline
\end{tabular}

Note: ${ }^{*} p<.05, * * p<.01,{ }^{* * *} p<.001$

\section{Discussion and conclusions}

This study has sought to show the extent to which the level of psychological maladjustment of victims is affected by social status in the group and by the profile of victimisation. The aim in choosing lack of social support and peer rejection suffered by victimised individuals - two group measurements regarded as social risk factors - as study variables was to assess whether these factors could influence the level of depression common to these individuals and to what extent. First of all, it was posited that there would be a higher level of depression in victimised children, which the results confirmed (Hypothesis 1). There are numerous reasons for the presence of depression in boys and girls, and victimisation in bullying at school corresponds to only a small number of the total amount of students with depression. This would explain the small scale of the effect of the first step in both linear regression models, in which only victimisation and lack of social support were included in the first model and victimisation and rejection in the second. The relationship found in this study between victimisation and depression is in line with the findings of previous studies by other authors (Branson \& Cornell, 2009; Hodges \& Perry, 1999; Olweus, 1978; Swearer et al., 2001).

This study also analysed - jointly - the extent to which victimisation was affected by lack of social status in the group or by the status of being socially rejected. However, the results were not conclusive with regard to an increase in depression linked with victims with these traits. It was expected that the level of social support of victimised individuals would result in lower levels of depression when the victimised student had social support in the class group. It was 
shown that the presence of social support in the class group mitigates the effect of victimisation behaviours relating to depression. Victims displayed a greater level of depression when they did not have social support in the class group than when they had support, confirming Hypothesis 2a. These results support the findings of other authors who have noted the mitigating effect of social support on the psychological adjustment of victimised individuals, while detecting lower levels of depression in victims with social support in the classroom than in victims who have no social support in the class group (Flaspohler et al., 2009; Holt \& Espelage, 2007; Pellegrini et al., 1999; Sainio et al., 2010; Salmivalli, 2010; Salmivalli, Voeten \& Poskiparta, 2011).

It was expected that a higher level of depression would be found in victimised students who have been rejected by the group (Hypothesis $2 \mathrm{~b}$ ). However, there was shown to be no link with depression and no interaction effect on the other variables. The effect of rejection on victimisation seems to take the form of a special relationship: although most victimised students are rejected, not all rejected students are victimised, and this variable does not, in itself, influence depression. There is no link between the levels of depression suffered by victimised students and the level of rejection they experience. The group of rejected victims with no social support do not, therefore, have greater levels of depression than victims with no support. Although most studies have revealed a link between rejection and victimisation (Graham \& Juvonen, 1998; Hodges et al., 1997; Martínez \& Delgado, 2006; Olweus, 1978; Perry et al., 1988; Salmivalli, 2010), there have been few works to date that have studied the link between social support and rejection comparatively and none have studied rejection, victimisation and depression jointly. Consequently, these results cannot be compared with previous ones.

Finally, the level of depression of victimised individuals is not the same in all cases. Taking into consideration the heterogeneity of the group of victims and in following the recommendation that the personality traits of victims should be studied separately (Graham, Bellmore \& Juvonen, 2003), it was posited that a higher level of depression would be found in victims with a withdrawn profile than in those with an externalising profile (Hypothesis 3). The profile presented by victims was therefore analysed to see if it had an influence on the level of depression they suffered. As posited, victims with a withdrawal profile - usually associated with passive victims (Avilés, 2009; Kochenderfer \& Ladd, 1996) - revealed a higher level of depression than victims who were not very withdrawn. This data coincides with that encountered by other studies (Batsche \& Knoff, 1994). It should also be pointed out that in regard to victimised students with withdrawal traits, results show that a lack of social support is associated with an increase in levels of depression. We have not come across any references in this respect in international research. Our results also show that the presence of a higher level of impulsiveness, linked to a profile of victimisation with externalising traits (Martínez \& Delgado, 2006; Per- ry et al., 1988) did not have a significant influence on the relationship between victimisation and depression, which contradicts the findings of other authors who have identified a relationship between victims with externalising traits and depression, even at levels higher than those of victims with internalising traits (Branson \& Cornell, 2009; Swearer et al., 2001). The explanation behind this may be linked to the fact that victimised students with externalising traits receive the least social support (Hodges et al., 1997), which would increase their levels of depression. However, as our results show, this study did not identify that effect.

In summary, experiences of bullying at school are linked to increased peer rejection, which leads to victims suffering greater isolation from the group, without any possibility of receiving the support of their classmates in dealing with the conflicts and threats to which they are exposed on a daily basis, resulting in a reduction in social support in the classroom (Hodges et al., 1997; Hodges \& Perry, 1999; Perry et al., 1988). A lack of social support also increases the possibility of being victimised, given that aggressors usually seek out victims who are disadvantaged and insecure. And suffering victimisation also increased the risk of being rejected (Graham \& Juvonen, 1998; Perry et al., 1988; Salmivalli, 2010). This vicious circle reduces the possibilities of having a stable social support network and creates a situation whereby victimisation continues. This seems to show, therefore, that what genuinely influences the psychological maladjustment of victimised students, in terms of levels of depression, is lack of social support, with the effects on this variable in the different victim profiles and in the level of rejection being found to be non-conclusive. These results show the importance of social support in the class group. Students spend many hours with the same peers over prolonged periods of time (months and even years). Conflicts, to a greater or lesser degree, will occur between them, and efforts to prevent bullying and its effects should not focus solely on the aggressive behaviour of those who intimidate others or on teaching victims suitable confrontation strategies, but on attaching greater importance to the creation of stable and secure links between the members of the class group. Social support in the class group thus performs a stabilising function that can mitigate some of the adverse effects that arise in everyday conflict, even in serious cases. This proposal was made by Perry and his team (1988) on identifying the importance of social support in the classroom as a means of protection against school victimisation. Schools and their teaching staff must promote spaces, opportunities and channels for the creation of links between students, support groups, stable social networks, etc., and create the necessary resources for ensuring that these links are solid, secure and based on the mutual respect of the individuals who form part of them. Continuous monitoring is also essential, as is the need to set up mechanisms that ensure that all students are included in a social group in their school environment and, more specifically, in their classroom. The creation of sociograms in the classroom can provide the information needed to prevent students 
from feeling helpless. Such preventative work should be carried out prior to direct intervention in recognised cases of peer-to-peer bullying.

As regards peer rejection, it is surprising that this indicator does not impact on the depression experienced by victims, as would be expected. Although the results support, above all, the need to create support links in the class group, we do not believe that the lack of influence of rejection in our study necessarily means that it is not worthy of consideration. This is because, first and foremost, previous studies have identified a clear link with a greater number of rejections suffered by victimised students (e.g. Dijkstra, Lindenberg \& Veenstra, 2008; Martínez \& Delgado, 2006; Olweus, 1978). Furthermore, rejection is a natural adaptive behaviour in situations of risk or danger but is not suitable in a school environment in which harmony and respect for equals are paramount. There is also the fact that rejection is usually a group behaviour, which labels the individuals suffering from it and limits their chances of no longer being rejected. Efforts must therefore be made to prevent peer rejection caused by differences between classmates by teaching respect for diversity and encouraging other more positive behaviours when conflict or unfavourable situations arise. The

\section{References}

Arnaiz, P., Cerezo, F., Giménez, A. M., \& Maquilón, J. J. (2016). Online addiction behaviors and cyberbullying among adolescents. Anales de Psicología, 32(3), 761-769. doi: 10.6018/analesps.32.3.217461

Achenbach, T. M., \& Edelbrock, C. S. (1978). The classification of child psychopathology: a review and analysis of empirical efforts. Psychological Bulletin, 85(6), 1275-1301. doi: 10.1037/0033-2909.85.6.1275

Aiken, L. S., \& West, S. G. (1991). Multiple Regression: Testing and interpreting interactions. Newbury Park, CA: Sage.

Asher, S. R., \& Dodge, K. A. (1986). Identifying children who are rejected by their peers. Developmental Psychology, 22(4), 444-449. doi: 10.1037/0012-1649.22.4.444

Avilés, J. M. (2009). Victimización percibida y bullying. Factores diferenciales entre víctimas. Boletin de Psicología, 95, 7-28.

Avilés, J. M., \& Monjas, I. (2005). Estudio de incidencia de la intimidación y el maltrato entre iguales en la educación secundaria obligatoria mediante el cuestionario CIMEI (Avilés, 1999) -Cuestionario sobre Intimidación y Maltrato Entre Iguales-. Anales de Psicología, 21, 27-41

Batsche, G. M., \& Knoff, H. M. (1994). Bullies and their victims: Understanding a pervasive problem in the schools. School Psychology Review, 23, 165-174.

Boivin, M., Hymel, S., \& Bukowski, W. M. (1995). The roles of social withdrawal, peer rejection, and victimization by peers in predicting loneliness and depressed mood in children. Development and Psychopathology, 7(4), 765-785. doi: 10.1017/S0954579400006830

Boulton, M.J., \& Smith, P.K. (1994). Bully/victim problems in middleschool children: Stability, self-perceived competence, peer perceptions, and peer acceptance. British Journal of Developmental Psychology, 12(3), 315329. doi: 10.1111/j.2044-835X.1994.tb00637.x

Boulton, M. J., \& Underwood, K. (1992). Bully victim problems among middle school children. British Journal of Educational Psychology, 62(1), 7387. doi: 10.1111/j.2044-8279.1992.tb01000.x

Branson, C. E., \& Cornell, D. G. (2009). A comparison of self and peer reports in the assessment of middle school bullying. Journal of Applied School Psychology, 25(1), 5-27.

Buhs, E. S., \& Ladd, G. W. (2001). Peer rejection as antecedent of young children's school adjustment: An examination of mediating processes. victims of bullying at school and aggressors should also be encouraged to develop emotional skills with a view to minimising its effects as far as is possible.

Having analysed the limitations of this study, it should be complemented by more specific studies to enable assessment of the quality of social support and their ability as protective agents, as well as the influence of family support. In this respect, and in line with other studies such as that conducted by Arnaiz, Cerezo, Giménez and Maquilón (2016), we believe it necessary to investigate the prevalence of depression in isolated students, whose isolation is linked to a lack of social support and negligible support from their families and which results in them becoming victims, even though they do not figure among the group of victims revealed through hetero-reporting.

With regard to the contradictions found in our study, and in terms of the link between the level of depression and the type of victimisation. It is required a separate analysis of groups of victims in relation to social support and other internalising and externalising variables of these individuals. This may provide clearer data. To achieve this, future studies should contemplate non-reciprocal nominations and study their association with depression.
Developmental Psychology, $\quad 37(4), \quad 550-560 . \quad$ doi: $\quad 10.1037 / 0012-$ 1649.37.4.550

Cairns, R. B., Cairns, B. D., Neckerman, H. J., Gest, S. D., \& Gariepy, J. L. (1988). Social networks and aggressive behavior. Developmental Psychology, 24(6), 815-823. doi: 10.1037/0012-1649.24.6.815

Cerezo, F., Sánchez, C., Ruiz, C., \& Arense, J. (2015). Roles en bullying de adolescentes y preadolescente, y su relación con el clima social y los estilos educativos parentales. Revista de Psicodidáctica, 20(1), 139-155. doi: 10.1387 /revPsicodidact.11097

Coie, J. D., Dodge, K. A., \& Coppotelli, H. (1982). Dimensions and types of social status: A cross-age perspective. Developmental Psychology, 18(4), 557-570. doi: 10.1037/0012-1649.18.4.557

Dijkstra, J. K., Lindenberg, S., \& Veenstra, R. (2008). Beyond the class norm: Bullying behavior of popular adolescents and its relation to peer acceptance and rejection. Journal of Abnormal Child Psychology, 36(8), 1289-1299. doi: 10.1007/s10802-008-9251-7

Espelage, D.L., \& Holt, M. K. (2013). Suicidal ideation and school bullying experiences after controlling for depression and delinquency. Journal of Adolescent Health,53(1), 27-31. doi: 10.1016/j.jadohealth.2012.09.017

Flaspohler, P. D., Elfstrom, J. L., Vanderzee, K. L., Sink, H. E., \& Birchmeier, Z. (2009). Stand by me: The effects of peer and teacher support in mitigating the impact of bullying on quality of life. Psychology in the Schools, 46(7), 636-649. doi: 10.1002/pits.20404

Garandeau, C. F., \& Cillessen, A. H. (2006). From indirect aggression to invisible aggression: A conceptual view on bullying and peer group manipulation. Aggression and Violent Behavior, 11(6), 612-625.

Goossens, F. A., Olthof, T., \& Dekker, P. (2006). The New Participant Role Scales: A comparison between various criteria for assigning roles and indications for their validity. Aggressive Behavior, 32, 343-357. doi: 10.1002/ab.20133

Graham, S., \& Juvonen, J. (1998). Self-blame and peer victimization in middle school: An attributional analysis. Developmental Psychology, 34, 587-599. doi: 10.1037/0012-1649.34.3.587

Graham, S., Bellmore, A., \& Juvonen, J. (2003). Peer victimization in middle school: When self-and peer views diverge. Journal of Applied School Psychology, 19(2), 117-137. 
Haynie, D. L., Nansel, T., Eitel, P., Davis-Crump, A., Saylor, K., Yu, K., \& Simons-Morton, B. (2001). Bullies, victims, and bully/victims: Distinct groups of atrisk youth. Journal of Early Adolescence, 21, 29-49. doi: $10.1177 / 0272431601021001002$

Hodges, E. V., Malone, M. J., \& Perry, D. G. (1997). Individual risk and social risk as interacting determinants of victimization in the peer group. Developmental Psychology, 33(6), 1032-1039.

Hodges, E. V., \& Perry, D. G. (1999). Personal and interpersonal antecedents and consequences of victimization by peers. Journal of Personality and Social Psychology, 76(4), 677-685.

Holt, M. K., \& Espelage, D. L. (2007). Perceived social support among bullies, victims, and bully-victims. Journal of Youth and Adolescence, 36(8), 984-994. doi: 10.1007/s10964-006-9153-3

Huitsing, G., \& Veenstra, R. (2012). Bullying in classrooms: Participant roles from a social network perspective. Aggressive Behavior, 38(6), 494 509. doi: $10.1002 / \mathrm{ab} .21438$

Juvonen, J., \& Graham, S. (Eds.) (2001). Peer harassment in school: The plight of the vulnerable and victimized. New York: Guilford Press.

Juvonen, J., Graham, S., \& Schuster, M. A. (2003). Bullying among young adolescents: The strong, the weak, and the troubled. Pediatrics, 112(6), 1231-1237. Recuperado http:/ / www.pediatrics.org/cgi/content/full/112/6/1231

Kochenderfer, B. J., \& Ladd, G. W. (1996). Peer victimization: Cause or consequence of school maladjustment? Child Development, 67(4), 13051317. doi: 10.1111/j.1467-8624.1996.tb01797.x

López, V., Bilbao, M. A., \& Rodríguez, J. I. (2012). La sala de clases sí importa: incidencia del clima de aula sobre la percepción de intimidación y victimización entre escolares. Universitas Psychologica, 11(1), 91-101.

Machimbarrena, J. M., \& Garaigordobil, M. (2017). Bullying/Cyberbullying en quinto y sexto curso de primaria: diferencias entre centros públicos y privados. Anales de Psicología, 33(2), 319-326. doi: 10.6018/analesps.33.2.249381

Manga, D., Abella, V., Barrio, S., \& Álvarez, A. (2007). Tipos de Adolescentes según la Soledad y el Acoso Escolar Percibido: Diferencias en personalidad y apoyo social. TIPICA. Boletín Electrónico de Salud Escolar, 3(1). Recuperado http://www.tipica.org/pdf/manga_tipos_de_adolescentes_segun_la_s oledad_y_el_acoso_escolar.pdf

Martín, J., Ruiz, E., \& Martínez, R. (2014). Desajuste psicológico de las victimas de acoso escolar: Un análisis evolutivo desde la educación primaria hasta la secundaria. Madrid, España: Colegio Oficial de Psicólogos de Madrid y Fundación Atresmedia.

Martínez, M. R., \& Delgado, P. (2006). La agresión entre iguales en la educación secundaria obligatoria: tipología de conductas y diferencias entre los grupos. Acción Psicológica, 4(2), 183-198.

Nolasco, A. (2012). La empatía y su relación con el acoso escolar. Revista de Estudios y Experiencias en Educación, 11(22), 35-54.

Olweus, D. (1978). Aggression in the schools: Bullies and whipping boys. Oxford, England: Hemisphere.

Olweus, D. (1993). Bullying at school. Cambridge, MA: Blackwell.

Olweus, D. (1994). Bullying at school: basic facts and effects of a school based intervention program. Journal of Child Psychology and Psychiatry, 35(7), 1171-1190. doi: 10.1111/j.1469-7610.1994.tb01229.x

Olweus, D. (1998). Conductas de acoso y amenaza entre escolares. Madrid, España: Ediciones Morata.

Olweus, D. (2001). Bullying at school: tacking theproblem. The OECD Observer, $225,24-26$.

Parellada, M. J., San Sebastián, J., \& Martínez, R. (2009). Manual Esperi de trastornos del comportamiento en niños y adolescentes. Madrid, España: EOS.

Pellegrini, A. D., Bartini, M., \& Brooks, F. (1999). School bullies, victims, and aggressive victims: factors relating to group affiliation and victimi- zation in early adolescence. Journal of Educational Psychology, 91(2), 216224. doi: 10.1037/0022-0663.91.2.216

Perry, D. G., Kusel, S. J., \& Perry, L. C. (1988). Victims of peer aggression. Developmental Psychology, 24(6), 807-814. doi: 10.1037/0012 1649.24.6.807

Peets, K., Hodges, E., \& Salmivalli, C. (2011). Relationship specificity of aggressogenic thought-behavior processes. Journal of Personality and Social Psychology, 101(2), 386-400. doi: 10.1037/a0023662

Postigo, S., González, R., Montoya, I., \& Ordoñez, A. (2013). Theoretical proposals in bullying research: a review. Anales de Psicología, 29(2), 413425. doi: 10.6018/analesps.29.2.148251.

Rigby, K. (2002). New perspectives on bullying. London: Jessica Kingsley Publishers.

Sainio, M., Veenstra, R., Huitsing, G., \& Salmivalli, C. (2010). Victims and their defenders: A dyadic approach. International Journal of Behavioral Development, 35(2), 144-151. doi: 10.1177/0165025410378068

Salmivalli, C., \& Nieminen, E. (2002). Proactive and reactive aggression among school bullies, victims, and bully-victims. Aggressive Behavior, 28(1), 30-44. doi: 10.1002/ab.90004

Salmivalli, C. (2010). Bullying and the peer group: A review. Aggression and violent behavior, 15(2), 112-120. doi: 10.1016/j.avb.2009.08.007

Salmivalli, C., Voeten, M., \& Poskiparta, E. (2011). Bystanders matter: Associations between reinforcing, defending, and the frequency of bullying behavior in classrooms. Journal of Clinical Child y Adolescent Psychology, 40(5), 668-676. doi: 10.1080/15374416.2011.597090

Schwartz, D., Dodge, K. A., \& Coie, J. D. (1993). The emergence of chronic peer victimization in boys' play groups. Child Development, 64(6), 1755-1772. doi: 10.2307/1131467

Schwartz, D., McFadyen-Ketchum, S. A., Dodge, K. A., Pettit, G. S., \& Bates, J. E. (1998). Peer group victimization as a predictor of children's behavior problems at home and in school. Development and Psychopathology, 10(1), 87-99. doi: 10.1017/S095457949800131X

Solberg, M. E., \& Olweus, D. (2003). Prevalence Estimation of School Bullying with the Olweus Bully/Victim Questionnaire. Aggressive Behavior, 29(3), 239-268._doi: 10.1002/ab.10047

SPSS, Inc. (2013). IBM SPSS Statistics for Windows, Version 22.0. Armonk, NY: IBM Corporation.

Swearer, S. M., Song, S. Y., Cary, P. T., Eagle, J. W., \& Mickelson, W. T. (2001). Psychosocial correlates in bullying and victimization: The relationship between depression, anxiety, and bully/victim status. Journal of Emotional Abuse, 2(2-3), 95-121. doi: 10.1300/J135v02n02_07

Toblin, R.L., Schwartz, D., Hopmeyer Gorman, A., \& Abo-ezzedine, T. (2005). Social-cognitive and behavioural attributes of aggressive victims of bullying. Applied Developmental Psychology, 26(3), 329-346. doi: 10.1016/j.appdev.2005.02.004

Unnever, J. D., \& Cornell, D. G. (2003). The culture of bullying in middle school. Journal of School Violence, 2(2), 5-27. doi: 10.1300/J202v02n02 02

Unnever, J. D. (2005). Bullies, aggressive victims, and victims: Are they distinct groups? Aggressive Behavior, 31(2), 153-171. doi: 10.1002/ab.20083

Veenstra, R., Lindenberg, S., Munniksma, A., \& Dijkstra, J. K. (2010). The Complex Relation Between Bullying, Victimization, Acceptance, and Rejection: Giving Special Attention to Status, Affection, and Sex Differences. Child Development, 81(2), 480-486. doi: 10.1111/j.1467-8624.2009.01411.x

Veenstra, R., Lindenberg, S., Oldebinkel, A. J., de Winter, A. F., Verbulst, F. C., \& Ormel, J. (2005). Bullying and victimization in elementary schools: A comparison of bullies, victims, bully/victims, and uninvolved preadolescents. Developmental Psychology, 41(4), 672-682. doi: 10.1037/0012-1649.41.4.672

Wright, J. C., Giammarino, M., \& Parad, H. W. (1986). Social status in small groups: Individual-group similarity and the social "misfit". Journal of Personality and Social Psychology, 50(3), 523-536. doi: 10.1037/00223514.50.3.523 